\title{
Influence of subtilisin on the adhesion of a marine bacterium which produces mainly proteins as extracellular polymers
}

\author{
C. Leroy ${ }^{1,2}$, C. Delbarre ${ }^{1}$, F. Ghillebaert ${ }^{2}$, C. Compere $^{3, *}$ and D. Combes ${ }^{4}$ \\ ${ }^{1}$ IFREMER, Laboratoire de Biotechnologie et Molécules Marines, Nantes, France \\ ${ }^{2}$ Mexel S.A. Verberie, France \\ 3 IFREMER, Service Interfaces et Capteurs, Brest, France \\ ${ }^{4}$ UMR CNRS 5504, UMR INRA 792, INSA, Laboratoire Biotechnologie-Bioprocédés, Toulouse, France \\ *: Corresponding author : Compere C., email address : chantal.compere@ifremer.fr
}

\begin{abstract}
:
Aims: The nature of exopolymers involved in the adhesion of a marine biofilm-forming bacterium Pseudoalteromonas sp. D41 was investigated to evaluate and understand the antifouling potential of subtilisin.

Methods and Results: The exopolymers of D41 produced by fermentation were analysed by FTIR and SDS-PAGE showing the presence of polysaccharides, glycoproteins and proteins. A high content of proteins was detected both in soluble and capsular fractions. The microscopic observations of fluorescamine and calcofluor stained adhered D41 indicated mainly the presence of proteins in exopolymers produced during adhesion. Subtilisin, the broad spectrum protease, tested in natural sea water and in polystyrene microplates showed that antifouling activity was higher in the prevention of bacterial adhesion than in the detachment of adhered D41 cells.

Conclusions: Overall, these results demonstrate the involvement of proteins in Pseudoalteromonas sp. D41 adhesion and confirm the high antifouling potential of subtilisin.

Significance and Impact of the Study: This study emphasizes the major role of proteins instead of polysaccharides, thus extending our knowledge regarding the nature of extracellular polymers involved in bacterial adhesion. Furthermore, the high antifouling potential of subtilisin evaluated in the very first stages of fouling, bacterial adhesion, could lead to less toxic compounds than organometallic compounds in antifouling paint.
\end{abstract}

Keywords: biofilm, exopolymer, subtilisin, Pseudoalteromonas, antifouling, capsular protein. 


\section{Introduction}

Marine biofilm is described as one of the first steps in fouling formation. It is composed of organic (proteics and osidic fragments) and inorganic compounds like salts (Compère et al., 2001), bacteria and microalgae (Wahl, 1989). Bacteria colonize the surface thanks to appendages and envelope structures such as flagella, pili, peptidoglucan or adhesin (Lejeune, 2003) and consequently build up a biofilm. This latter consists of bacteria embedded in their slime, composed mainly of extracellular polymeric substances (EPS) such as polysaccharides or proteins (Sutherland, 2001; Allison, 2003; Branda et al., 2005).

Exopolysaccharides have been the most studied EPS up to now. They are described as directly involved in the architecture of biofilm and several of them have already been characterised. Surprisingly, extracellular proteins have been less studied and although their presence in biofilm has been demonstrated (Jahn et al., 1999; van der Aa and Dufrene, 2002; Donlan et al., 2004, Kogan et al., 2006), few studies have explored with the nature or primary structure of these proteins and their role in attachment to surfaces has not been elucidated yet. Some proteins could be indirectly involved in biofilm formation such as enzymes which could lead to polysaccharide synthesis as already described in dental biofilm (Welin et al., 2004). Proteins in Pseudomonas aeruginosa biofilm can represent 30\% of total EPS biomass, with molecular masses averaging 50 to $150 \mathrm{kDa}$ and exhibit a high proteolytic activity (Flemming and Wingender, 2001). Considering cell-wall anchored proteins, some of them can be directly involved in biofilm formation such as adhesins involved in Escherichia Coli adhesion (Roux et al., 2005) or like surface proteins Bap, Esp and BapA and have been directly involved in Staphylococcus aureus, Enterococcus faecalis and Salmonella enteritidis biofilms respectively (Curacella et al., 2001; Toledo-Arana et al., 2001; Latasa et al., 2005). Pseudoalteromonas sp. D41 is a marine biofilm-forming bacteria isolated from a natural $24 \mathrm{~h}$ marine biofilm formed in the bay of Brest (France) (Rubio, 2002). A previous study of its chemical composition surface highlighted the presence of proteins in its upmost layer (Pradier et al., 2005). Therefore, we decided to study extracellular polymeric substances (EPS) excreted by Pseudoalteromonas sp. D41. In this study, the biochemical analysis of EPS produced by Pseudoalteromonas $s p$. D41 was performed both after fermentation by FTIR and SDS PAGE analysis and upon adhesion by epifluorescence microcoscopy using DAPI (4'6-diamidino-2-phenylindole), calcofluor and fluorescamine stains for DNA, $\beta$-glucans and protein detection respectively. Results show a high rate of protein content both in EPS excreted during fermentation, especially in capsular fraction, and upon bacterial adhesion.

Fouling on marine underwater surfaces causes critical and economic problems such as extensive material biodamages and industrial performance reductions. The use of biocides like organometallic compounds causes environmental problems and European regulations regarding antifouling paints are becoming increasingly restrictive, banishing organostannic use on all vessels in 2008 (Directive $98 / 8 / C E)$. Finding environmentally friendly antifouling compounds has thus reached emergency proportions today. The control of biofilm development by hydrolysing organic compounds involved in the first steps of adhesion using enzymatic treatments is one strategy to prevent fouling. Enzymes compared to organometallic compounds show more biodegradability, weak toxicity and inhibit adhesion instead of killing fouling organisms. Alcalase and Savinase have demonstrated high antifouling potential by inhibiting the adhesion of fouling macroorganisms, such as cypris larvae and the spores of green alga or diatoms (Pettitt et al., 2004), and fouling microorganisms, such as Pseudoalteromonas sp. D41 (Leroy et al., in press) respectively. These two commercial enzymatic preparations are based on subtilisin, a broad spectrum protease. Moreover, the effectiveness of enzymatic treatments seems to depend on EPS chemical composition (Chaignon et al., 2007). Therefore, the antifouling properties of subtilisin were studied in solution, in terms of the prevention of bacterial adhesion and of the detachment of adhered bacteria using previous marine bacterial adhesion microplate tests (Leroy et al., 2007).

\section{Materials and methods}

All the chemicals and reagents were of analytical grade from Sigma-Aldrich. 


\section{Biofilm forming bacterium}

The D41 strain was isolated from a natural marine biofilm on Teflon coupons after 24 hour immersion in the bay of Brest (France) (Rubio, 2002). For long-term storage, pure culture was maintained on Difco Marine Broth (MB) 2216E (Fischer Scientific Labosi, Elancourt, France) with 15\% (v/v) glycerol at $-80^{\circ} \mathrm{C}$. A comparative $16 \mathrm{~S}$ rRNA gene sequences analysis indicated that the D41 isolate belonged to the genus Pseudoalteromonas sp. (Rubio, 2002).

\section{EPS study}

EPS production was performed in a 5 I fermentor as described by Raguenes et al. (1997). Detailed procedures relating to extraction/purification were carried out as published by Samaïn et al (1997). Briefly, the two soluble EPS were isolated from the fluid supernatant recovered from the medium by high-speed centrifugation $\left(20000 \mathrm{~g}, 2 \mathrm{~h}, 4^{\circ} \mathrm{C}\right)$. EPS2 fraction was obtained from the retentate of an ultrafiltration on $100 \mathrm{kDa}$ membrane. A subsequent ultrafiltration of the filtrate on a $10 \mathrm{kDa}$ membrane gave EPS1 fraction (retentate). Capsular fraction EPS3 was recovered from the cell pellet by dialysis (cut off 6-8 kDa). All fractions were lyophilized.

The amount of neutral carbohydrate was determined using the orcinol-sulfuric method with glucose as the standard as described by Tillmans and Philippi (1929) and modified by Rimington (1931). The protein content was determined by BCA assay with Bovine Serum Albumin (BSA) as the standard (Smith et al., 1985). Inorganic matter content was calculated by thermogravimetric analysis performed with a thermal analysis TGA 92. The weight loss was recorded while the EPS sample was being heated from $20^{\circ} \mathrm{C}$ to $700^{\circ} \mathrm{C}$ at a scanning rate of $10^{\circ} \mathrm{C}$ per minute and maintained at $700^{\circ} \mathrm{C}$ for 8 hours. The inorganic matter content was evaluated from the residual weight at $700^{\circ} \mathrm{C}(\mathrm{wt} \%)$.

EPS fraction composition in carbohydrate and protein was then calculated as the percentage of organic matter (in $\mathrm{mg}$ for $100 \mathrm{mg}$ of organic matter).

For infra-red spectroscopy analyses, $2 \mathrm{mg}$ of dried EPS was mixed with dry potassium bromide $(\mathrm{KBr})$ and pelleted. The pellet was analysed on FTIR Bruker Vector 22 and spectra were recorded between 4000 and $400 \mathrm{~cm}^{-1}$ region with a resolution of $4 \mathrm{~cm}^{-1}$.

The EPS fractions were analysed under denaturing and reducing conditions on $8 \%$ SDSPAGE according to Laemmli's method (Laemmli, 1970) and using the Mini Protean III Bio-Rad. 0.12 mg of each EPS fraction was loaded per lane and gels were stained with Coomassie blue or Shiff's reagent. For Coomassie blue staining, gels were fixed and colored in 50\% ethanol, 10\% acetic acid and $0.25 \%$ Coomassie blue solution, and discoloured in 30\% ethanol, 10\% acetic acid. For Shiff's reagent staining, gels were fixed in $25 \%$ isopropanol, $10 \%$ acetic acid, incubated successively 30 min in $7.5 \%$ acetic acid, $1 \mathrm{~h}$ in $0.2 \%$ periodic acid, $1 \mathrm{~h}$ in Shiff's reagent and then discoloured in $7.5 \%$ acetic acid.

For microscopic analysis, Pseudoalteromonas sp. D41 was grown overnight on Difco Marine Agar (MA) 2216E (Fischer Scientific Labosi, Elancourt, France) at $25^{\circ} \mathrm{C}$, scraped and suspended in natural sea water sterilized by filtration through a $0.22 \mu \mathrm{m}$ to reach an OD600nm of $2(\sim 2 \times 109 \mathrm{cfu}$ ml-1). 900 $\mu \mathrm{l}$ of bacterial suspension were inoculated into Lab-Tek ${ }^{\mathrm{TM}}$ wells with a glass surface (Lab-Tek ${ }^{\mathrm{TM}}$ NUNC, Fischer Scientific Labosi). Covered Lab-Tek ${ }^{T M}$ were incubated for $24 \mathrm{~h}$ at $20^{\circ} \mathrm{C}$ with orbital shaking (300 r.p.m.). Non adhered bacteria were removed by three successive hand washings: Lab$\mathrm{Tek}^{\mathrm{TM}}$ wells were emptied, $900 \mu \mathrm{l}$ of $36 \mathrm{~g} \mathrm{I}-1$ sterile $\mathrm{NaCl}$ solution was added and Lab-Tek ${ }^{\mathrm{TM}}$ were shaken. The adhered bacteria were fixed for $1.5 \mathrm{~h}$ at $4^{\circ} \mathrm{C}$ with $900 \mu \mathrm{l}$ of sterile $36 \mathrm{~g} \mathrm{l}-1 \mathrm{NaCl}$ solution containing $2.5 \%$ formaldehyde and then desalted by successive baths with decreasing salinity solutions. For DAPI staining, adhered bacteria were incubated with $900 \mu \mathrm{l}$ of $4 \mu \mathrm{g} \mathrm{ml}-1$ DAPI for 20 $\mathrm{min}$ in the dark. For calcofluor staining, adhered bacteria were incubated with $900 \mu \mathrm{l}$ of $0.1 \mathrm{mg} \mathrm{ml}-1$ calcofluor white M2R for $1 \mathrm{~h}$ in the dark. For fluorescamine staining, adhered bacteria were incubated for $5 \mathrm{~min}$ in the dark with $900 \mu \mathrm{l}$ of $0.1 \mathrm{mg} \mathrm{m}^{-1}$ fluorescamine, previously solubilized in acetone at 0.2 $\mathrm{mg} \mathrm{ml}^{-1}$ and half diluted in buffer phosphate borate $0.4 \mathrm{~mol} \mathrm{I}^{-1} \mathrm{pH} \mathrm{9.7}$. The excess stain was removed by three hand washings with water or with buffer phosphate borate for the fluorescamine staining protocol. The Lab-Tek ${ }^{\mathrm{TM}}$ wells were removed, and the glass surfaces were dried out. The slides were observed under 100 magnification epifluorescence microscopy using an Olympus BH201 under UV filter. 


\section{Bacterial adhesion experiments}

The subtilisin was purchased from Sigma-Aldrich. Its effect on Pseudoalteromonas sp. D41 adhesion in black polystyrene microtiter plates (Microwell F96 FluoroNunc, Bioblock, Illkirch, France), in natural sea water sterilized by filtration through a $0.22 \mu \mathrm{m}$, at $20^{\circ} \mathrm{C}$ was studied as described in Leroy et al. (2007).

The enzymes were tested in two ways.

The inhibition of bacterial adhesion (the prevention test),

$50 \mu \mathrm{l}$ of the enzymatic preparation at the desired concentration was placed in the wells one hour before the bacterial suspension ( $200 \mu \mathrm{l}$ per well) and incubated for 3 and $24 \mathrm{~h}$ at $20^{\circ} \mathrm{C}$.

The detachment of adhered bacteria (the detachment test)

The enzymes were added 3 hours after the D41 bacterial suspension and incubated for $1 \mathrm{~h}$ at $20^{\circ} \mathrm{C}$.

In both tests, three washings in $36 \mathrm{~g} \mathrm{l}-1 \mathrm{NaCl}$ were performed before fixation for $1.5 \mathrm{~h}$ at $4^{\circ} \mathrm{C}$ with 200 $\mu \mathrm{l}$ of $36 \mathrm{~g} \mathrm{l}-1$ sterile $\mathrm{NaCl}$ containing $2.5 \%$ formaldehyde and DAPI staining $(4 \mu \mathrm{g} \mathrm{ml}-1)$ for $20 \mathrm{~min}$. Three washings were again performed to remove excess DAPI and then, the remaining bound DAPI was solubilized into ethanol 95\% for 15 min $(200 \mu l)$.

Fluorescence was measured at $350 \mathrm{~nm}$ excitation and $510 \mathrm{~nm}$ emission wavelengths using a Genios Plus microplate fluorescence reader (TECAN, Lyon, France). Each subtilisin solution within a large range of concentrations (from 18 to $0.56 \times 10^{-3} \mathrm{mg} \mathrm{ml}^{-1}$ ) was tested between twice and five times using two fold serial dilutions. Heat denatured subtilisin was obtained by heating subtilisin at $100^{\circ} \mathrm{C}$ for 20 min.

A blank with sterile seawater as well as a control with bacterial suspension without enzymes were included in each column of the experimental microplate. The change in bacterial adhesion was calculated as a Percentage Reduction (PR), calculated from the fluorescence of the blank ( $F_{B}$; without bacteria), the fluorescence of the control ( $F_{C}$; bacteria without enzyme) and the fluorescence of the sample $\left(F_{s}\right.$; bacteria and enzyme) (Equation (1)).

$\mathrm{PR}=\left\{\left[\left(\mathrm{F}_{\mathrm{C}}-\mathrm{F}_{\mathrm{B}}\right)-\left(\mathrm{F}_{\mathrm{S}}-\mathrm{F}_{\mathrm{B}}\right)\right] /\left(\mathrm{F}_{\mathrm{C}}-\mathrm{F}_{\mathrm{B}}\right)\right\} \times 100$

Subtilisin IC50 values were calculated from a three-parameter logistic equation fitted to all PR values $(p<0.05)$, with their standard deviation, by a non linear regression using Sigmaplot 9.0 software (Systat Software Gmbh, Erkrath, Deutschland).

\section{Enzyme assay}

Protease activity was assayed with azocasein (Tomarelli et al., 1949). Subtilisin was incubated at different concentrations, from 0.5 to $10 \mathrm{~g} \mathrm{I}^{-1}$, in natural sea water (previously filtered through a $0.22 \mu \mathrm{m}$ membrane), at $25^{\circ} \mathrm{C}$ with $2 \%$ azocasein in phosphate buffer of $\mathrm{pH} 8.15$. Samples were withdrawn at different incubation times from 3 to $12 \mathrm{~min}$. The reaction was stopped by adding $10 \%$ trichloroacetic acid. After centrifugation, the absorbance of the supernatant was measured at $450 \mathrm{~nm}$. One unit of protease activity (UP) was defined as the amount of enzyme required to produce an absorbance unit change per minute at $25^{\circ} \mathrm{C}$ at $\mathrm{pH} 8.15$.

\section{Results}

\section{EPS characterization}

Three EPS fractions were isolated from Pseudoalteromonas sp. D41 fermentation: two soluble fractions separated according to their molecular mass during ultrafiltration (EPS1, 10-100 kDa, and EPS2 $>100 \mathrm{kDa}$ ) and one capsular fraction (EPS3) separated from cell pellets by dialysis and centrifugation. Soluble and capsular EPS fractions were produced at 49.7 and $51.2 \mathrm{mg} \mathrm{l}-1$ of fermentation broth respectively. Biochemical characterization showed that the organic matter in EPS1, EPS2 and EPS3 consisted of 58, 30 and 15\% carbohydrates and 38, 69 and $80 \%$ proteins respectively. We found a higher amount of carbohydrates in EPS1 while the proteins amount is higher in EPS2 and above all in EPS3. Since glucose was the standard for the orcinol assay and BSA for the protein assay, the obtained values are relative and cannot be compared to each other.

The FTIR analysis of EPS shows high homology between the 3 fractions (Fig. 1). A high absorbance in the region of 1640-1650 and $1530-1550 \mathrm{~cm}^{-1}$ respectively considered as amide I and amide II bands and assigned as proteins was observed for the three fractions, with less intensity for EPS1 compared to EPS3. EPS1 shows intense bands at $1100-1000 \mathrm{~cm}^{-1}$ usually referred as $\mathrm{COC}, \mathrm{CO}$ and $\mathrm{COH}$ 
vibrations indicating a high content of polysaccharides in EPS1 fractions. These results confirm previous colorimetric assays.

Figure 2 shows the SDS PAGE analysis of the three fractions revealed by protein and carbohydrate stains. Unlike proteins, polysaccharide migration depends on their charges as well as on their molecular weight. Thus, the molecular weight of polysaccharides as well as glycoproteins can not be determined with molecular weight markers. A different proteic pattern with molecular weight under 150 $\mathrm{kDa}$ was displayed in all fractions. Although the EPS 2 fraction contains molecular weight molecules above $100 \mathrm{kDa}$, protein bands with molecular masses under $100 \mathrm{kDa}$ were displayed. This may be due to the denaturating and reducing conditions used, suggesting these bands could fit proteic subunits. The EPS1 fraction contained at least one polysaccharide. It also exhibited two bands which were coloured both by Coomassie blue and Shiff's reagent suggesting that these are two glycoproteins. No carbohydrate was shown in EPS2. However we could not rule out that EPS2 may well contain polysaccharides, as suggested by FTIR and carbohydrate dosages analysis, because even if no carbohydrate containing molecules are retained in the stacking gel, some polysaccharidic compounds might not be detected ; in fact, their size or their charge could prevent them from entering into the gel ; moreover, in the staining method involving oxidation by periodic acid, we expect that only 1,2-diol groups containing carbohydrates would be revealed. A large band between the two molecular weight markers of 100 and $150 \mathrm{kDa}$ was observed both by carbohydrate staining and protein staining suggesting the presence of glycoconjugate molecules such as glycoproteins or proteoglycans in capsular EPS (EPS3 fraction).

Pseudoalteromonas $s p$. D41 allowed to settle for $24 \mathrm{~h}$ on glass slide surfaces was observed by epifluorescence microscopy in order to compare EPS produced in fermented culture and in biofilm structure. Calcofluor, DAPI and fluorescamine were used to stain $\beta$-glucans, bacterial DNA and proteins $\left(\mathrm{NH}_{2}\right.$ extremity) respectively. Figure 3 shows that adhered bacteria retained more fluorescamine than calcofluor. DAPI staining indicated the total adhered bacteria on the surface. Epifluorescence microscopy showed that adhered Pseudoalteromonas sp. D41 produced EPS mainly composed of proteins. These results were correlated with the biochemical characterization of the EPS isolated from D41 fermentation.

\section{Subtilisin effect on bacterial adhesion}

Since proteins produced by Pseudoalteromonas sp. D41 are the main components of extrapolymeric substances, we investigated the antifouling potential of subtilisin, a protease with a broad substrate spectrum and which is active in sea water conditions (Fig. 4).

A sigmoid curve like dose-response curve was observed when plotting the adhesion inhibitions rate against the subtilisin concentrations in logarithmic scale (Fig. 4, row 2). All data could be fitted to a three-parameter logistic equation leading to IC50 values statistically significant at $99 \%$ for the prevention of adhesion and for the detachment of adhered bacteria (Table 1). Subtilisin showed non significant effects up to minimal concentration; above this level the response increased and reached a maximum effect or "plateau". Subtilisin reached a higher percentage reduction at lower proteolytic activity in the prevention than in the detachment test. Moreover, at maximal concentrations tested ( 0.5 UP ${ }^{-1}$ ), the inhibition rates in the 3 and 24 h prevention tests reached $99.5 \%$ but only reached $87 \%$ in the detachment of adhered cells. Subtilisin IC50 is 38 times better in the prevention of bacterial adhesion when allowed to set for $24 \mathrm{~h}$ than in bacteria detachment $(p=0.00001)$. The effectiveness of subtilisin in preventing bacterial adhesion is 13 times better when bacterial adhesion is allowed for 24 $\mathrm{h}\left(\mathrm{IC50}=0.0252 \mathrm{mg} \mathrm{ml}^{-1}\right)$ than for $3 \mathrm{~h}\left(\mathrm{IC} 50=0.333 \mathrm{mg} \mathrm{ml}^{-1}\right)(\mathrm{p}=0.012)$. The highest effective values of subtilisin were obtained in the prevention of bacterial adhesion allowed to set for $24 \mathrm{~h}$.

Surprisingly, heat denatured subtilisin showed partial inhibition of bacterial adhesion in the prevention test but not in the detachment test (Fig. 4, row 1).

\section{Discussion}

In the marine environment, enzymatic preparations can lead to the use of less harmful environmental agents in attempting to fight against the formation of bacterial biofilm. The purpose of our study was to investigate the antifouling potential of subtilisin regarding EPS nature involved in a marine bacterial adhesion model.

EPS studies on bacterial adhesion have mostly focused on exopolysaccharides. Exopolysaccharides are not the sole essential molecules in the development and structure of the biofilm matrix. Proteins in 
EPS fractions have been considered as contaminants stemming from the preparation (Nielsen and Jahn, 1999). Latasa et al. (2006) reviewed biofilm-associated proteins, in particular, a group of surface proteins promoting adhesion to surfaces; they are called Bap in Staphylococcus aureus and Salmonella enteritidis or Esp in Enterococcus faecalis. They are involved in primary attachment and biofilm formation on abiotic surfaces. Recently, it was shown that Staphyloccocus biofilm-forming strains produced extracellular acid teichoic and proteins instead of the usual poly- $\mathrm{N}$ acethylglucosamine (Kogan et al., 2006).

Many EPS studies have been performed on EPS isolated from culture media (Wingender et al., 1999) and more recently directly on biofilms (Neu and Lawrence, 1999; Kämper et al., 2004). It has been shown that bacteria in biofilm may present a different phenotype from bacteria in suspension, but differences in EPS produced by planktonic or biofilm bacteria could result from environmental adaptation of exopolymers. In this study, we have shown that the D41 EPS seems to have the same biochemical pattern in biofilm as in fermentation. EPS from biofilm and from planktonic bacteria can present differences in conformation, substitution and quantity but not necessarily in composition. Sutherland also thought that EPS from biofilm could have the same composition as EPS in planktonic bacteria (Sutherland, 2001). Beech et al. (1999) compared EPS produced by Pseudomonas sp. NCIMB 2021during fermentation and in biofilm. They displayed high homology in IR spectra, an increase in $\beta$-sheet conformation of the soluble EPS, and also differences in the level of substitution (O- and $\mathrm{N}$ - acetylation). More recently, a great degree of similarity has been shown between protein profiles in the proteomic analysis of Candida albicans from planktonic and biofilm growths (Thomas et al., 2006).

In this study, we have shown that the D41 EPS consists mainly of exopolysaccharides, proteins and glycoproteins. Proteins were in great amount in extracellular as well as in capsular fractions from liquid cultures and upon adhesion. These proteins could present, like in the EPS2 fraction, a molecular weight above $100 \mathrm{kDa}$ and could be composed of different sub-units. Moreover, the better effectiveness of subtilisin in the prevention test compared to that in the detachment test suggests that the protease activity is more effective during the very first stage of Pseudoalteromonas sp. D41 adhesion. This result stresses the major role of proteins in the intial steps of D41 adhesion.

Moreover, capsular exopolymers are not usually considered as necessary during the initial step of cell adhesion (Sutherland, 2001). We show in this publication that the capsular fraction was the EPS fraction which contains the most proteins. In fact, previous studies have demonstrated the presence of proteins in the chemical composition of Pseudoalteromonas sp. D41 surface upmost layer (Pradier et al., 2005). Since protease activity proved the most effective in reducing D41 adhesion (Leroy et al., in press), Pseudoalteromonas sp. D41 may well use a proteic mechanism to adhere to surfaces using extracellular proteins directly involved in bacterial adhesion, and maybe via capsular proteins.

Subtilisin is a serine endopeptidase with a broad substrate range. It has been shown that Alcalase, a commercial enzymatic preparation based on subtilisin, could inhibit the settlement and adhesion of fouling marine organisms such as cypris larvae of the barnacle, spores of green algae and diatoms (Pettitt et al., 2004). Since proteins are present in a great amount in D41 EPS components and Savinase (subtilisin) was the most effective hydrolase in both the prevention of bacterial adhesion and the removal of adhered bacteria (Leroy et al., in press), we have investigated the antifouling potential of subtilisin on D41 adhesion.

Heat denatured subtilisin partially inhibited bacterial adhesion in the prevention test. Since no residual protease activity was detected for heat denatured subtilisin (Leroy, 2006), this result suggests a non specific enzymatic effect, maybe due to the adsorption of enzymatic preparations (denatured enzymes and additives) which could lead to a partial inhibition of bacterial adhesion. This effect could only be observed in the prevention test and not in the detachment test suggesting that the adsorption of additives or denatured subtilisin on the surface, before bacterial adhesion, could modify the chemical properties of the surface and lead to a different bacterial adhesion. However, the effectiveness of subtilisin is significantly better when it is not heat denatured. Moreover, the longer the incubation time the more subtilisin inhibits bacterial adhesion in the prevention test. Furthermore, subtilisin is more effective than Savinase in the same D41 microplate adhesion test (Leroy et al., in press). These results all together suggest that the D41 adhesion inhibition effect is related to the enzymatic role of subtilisin.

As shown in Figure 4 and in Table 1, the effective concentrations of subtilisin for $50 \%$ inhibition of D41 adhesion (IC50) are 333, 25.2 and $970 \mathrm{mg} \mathrm{I}^{-1}$ in the $3 \mathrm{~h}$ prevention test, in the $24 \mathrm{~h}$ prevention test and in the detachment test respectively. These concentrations are higher than those of other biocides generally used in cooling water (Leroy et al., 2007) . But, in general, these products are used in continuous, shock or pulse dosing treatments and for a lower amount of bacteria than in our test 
condition. In fact, the number of adhered D41 in the wells is greater than the number of bacteria in a natural seawater biofilm. Under our test conditions, adhered D41 range from $2 \times 107$ to $2 \times 108$ bacteria per $\mathrm{cm} 2$ (Leroy et al., 2007) while $2.6 \times 103$ aerobic bacteria were counted on stainless steel coupons immersed for 60 days in a cooling seawater system (Lutterbach and França, 1996), or, depending on the season and coupon nature, $4 \times 105$ to $2 \times 107$ bacteria per $\mathrm{cm} 2$ were enumerated on 15 days immersed coupons in the Atlantic ocean (Brest bay) (Féra, 1985). Moreover, mixing subtilisin with other enzymes could improve the effective concentrations. In fact, a mixture of enzymes may lead to synergistic activity (Leroy, 2006). Moreover, grafting subtilisin onto the surface could also be an alternative in reducing the amount of required subtilisin.

The high amount of proteins produced by the D41 strain either in fermentation broth, particularly in the capsular fraction, or in biofilm together with the high inhibition effect of subtilisin on Pseudoalteromonas sp. D41 adhesion suggests that protein hydrolysis is the main mechanism involved in this inhibition process. This emphasizes the major role of proteins in the first step of Pseudoalteromonas sp. D41 adhesion.

\section{References}

Allison, D.G. (2003) The Biofilm matrix. Biofouling 19, 139-150.

Beech, I., Hanjagsit, L., Kalaji, M., Neal, A.L. and Zinkevich, V. (1999) Chemical and structural characterization of exopolymers produced by Pseudomonas sp. NCIMB 2021 in continuous culture. Microbiol 145, 1491-1497.

Branda, S.S., Vik, A., Friedman, L. and Kolter, R. (2005) Biofilms: the matrix revisited. Trends Microbiol 13, 20-26.

Chaignon, P., Sadovskaya, I., Ragunah, C., Ramasubbu, N., Kaplan, J.B. and Jabbouri, S. (2007) Susceptibility of staphylococcal biofilms to enzymatic treatments depends on their chemical composition. Appl Microbiol Biotechnol 75, 125-132.

Compère, C., Bellon-Fontaine, M.-N., Bertrand, P., Costa, D., Marcus, P., Paleunisn, C., Pradier, C.M., Rondot, B. and Walls, M.G. (2001) Kinetics of conditioning layer formation on stainless steel immersed in seawater. Biofouling 17, 129-145.

Curacella, C., Solano, C., Valle, J., Amorena, B., Lasa, I. and Penades, J.R. (2001) Bap, a Staphylococcus aureus surface protein involved in biofilm formation. J Bacteriol 183, 2888-2896.

Donlan, R.M., Piede, J.A., Heyes, C.D., Sanii, L., Murga, R., Edmonds, P., El-Sayed, I. and El-Sayed, M.A. (2004) Model system for growing and quantifying Streptococcus pneumoniae biofilms in situ and in real time. Appl Environ Microbiol 70, 4980-4988

Féra, P. (1985) Etude expérimentale de la colonisation par les bactéries de surfaces immergées en milieu marin. Ph. D. Thesis. University of Bretagne Occidentale.

Flemming, H.-C. and Wingender, J. (2001) Relevance of microbial extracellular polymeric substances (EPSs)-Part I: Structural and ecological aspects. Water Sci Technol 43, 1-8.

Jahn, A., Griebe, T. and Nielsen, P.-H. (1999) Composition of Pseudomonas putida biofilms: accumulation of protein in the biofilm matrix. Biofouling 14, 49-57.

Kämper, M., Vetterkind, S., Berker, R. And Hoppert, M. (2004) Methods for in situ detection and characterization of extracellular polymers in biofilms by electron microscopy. J Microbiol Meth 57, 5564.

Kogan, G., Sadovskaya, I., Chaignon, P., Chokr, A. and Jabbouri, S. (2006) Biofilms of clinical strains of Staphylococcus that do not contain polysaccharide intercellular adhesion. FEMS Microbiol Lett 255, 11-16.

Laemmli, U.K. (1970) Cleavage of structural proteins during the assembly of the head of bacteriophage T4. Nature 227, 680-685.

Latasa, C., Roux, A., Toledo-Arana, A., Ghigo, J.M., Gamazo, C., Penades, J.R. and Lasa, I. (2005) BapA, a large secreted protein required for biofilm formation and host colonization of Salmonella enterica serovar Enteritidis. Mol Microbiol 36, 10-23.

Latasa, C., Solano, C., Penades, J.R. and Lasa, I. (2006) Biofilm-associated proteins. C R Biol 329, 849-857.

Lejeune, P. (2003) Contamination of abiotic surfaces: what a colonizing bacterium sees and how to blur it. Trends Microbiol 11, 179-184.

Leroy, C. (2006) Lutte contre les salissures marines: approche par procédés enzymatiques. Ph. D. Thesis. University of Toulouse. 
Leroy, C., Delbarre-Ladrat, C., Ghillebaert, F., Rochet, M.J., Compere, C. and Combes, D. (2007) A marine bacterial adhesion microplate test using the DAPI fluorescent dye: a new method to screen antifouling agents. Lett Appl Microbiol 44, 372-378.

Leroy, C., Delbarre, C., Ghillebaert, F., Compère, C., Combes, D. (2007) Effects of commercial enzymes on the adhesion of a marine biofilm-forming bacterium. Biofouling In Press.

Lutterbach, M. T. S. and França, F. P. (1996) Biofilm formation in water cooling systems. World J Microbiol Biotechnol 12, 391-394.

Neu, T.R. and Lawrence, J.R. (1999) In situ characterization of extracellular polymeric substances (EPS) in biofilm systems. In Microbial extracellular polymeric substances ed. Wingender, J., Neu, T.R. and Flemming, H.C. pp. 21-47. Berlin: Springer.

Neu, T.R., Woelfl, S. and Lawrence, J.R. (2004) Three dimensional differentiation of photo-autotrophic biofilm constituents by multi-channel laser scanning microscopy (single photon and two-photon excitation). J Microbiol Meth 56, 161-172.

Nielsen, P.H. and Jahn, A. (1999) Extraction of EPS. In Microbial Extracellular Polymeric Substances ed. Wingender, J., Neu, T.R. and Flemming, H.C. pp. 49-72. Springer Berlin.

Pettitt, M.E., Henry, S.L., Callow, M.E., Callow, J.A. and Clare, A.S. (2004) Activity of commercial enzymes on settlement and adhesion of cypris larvae of the barnacle Balanus amphitrite, spores of the green alga Ulva Linza, and the diatom Navicula permituta. Biofouling 20, 299-311.

Pradier, C.-M., Rubio, C., Poleunis, C., Bertrand, P., Marcus, P. and Compere, C. (2005) Surface characterisation of three marine bacteria strains by FT-IR, XPS and ToF-SIMS, correlation with adhesion on stainless steel surfaces. J Phys Chem 109, 9540-9549.

Raguénès, G.H.C., Perès, A., Ruimy, R., Pignet, P., Christen, R., Loaec, M., Rougeaux, H., Barbier, G. and Guezennec, J.G. (1997) Alteromonas infernus sp. nov., a new polysaccharide-producing bacterium isolated from a deep-sea hydrothermal vent. J Appl Microbiol 82, 422-430.

Rimington, C. (1931) The carbohydrate complex of serum protein. II : Improved method of isolation and redetermination of structure. Isolation of glucosaminodimannose from protein of ox blood. Biochem J 25, 1062-1071.

Roux, A., Beloin, C. and Ghigo, J.M. (2005) Combined inactivation and expression strategy to study gene function under physiological conditions: application to identification of new Escherichia coli adhesins. J Bacteriol 187, 1001-1013.

Rubio, C. (2002) Compréhension des mécanismes d'adhésion des biofilms en milieu marin en vue de la conception de nouveaux moyens de prévention. Ph. D. Thesis. University of Paris 6.

Samaïn, E., Miles, M., Bozzi, L., Dubreucq, G. and Rinaudo, M. (1997) Simultaneous production of two different gel-forming exopolysaccharides by an Alteromonas strain originating from deep sea hydrothermal vents. Carbohydrate Polymers 34, 235-241.

Smith, P.K., Krohn, R.I., Hermanson, G.T., Mallia, A.K., Gartner, F.H., Provenzano, M.D., Fujimoto, E.K., Goeke, N.M., Olson, B.J. and Klenk, D.C. (1985) Measurement of protein using bicinchoninic acid. Anal Biochem 150, 76-85.

Sutherland, I.W. (2001) The biofilm matrix - an immobilized but dynamic microbial environment. Trends Microbiol 9, 222-227.

Thomas, D.P., Bachmann, S.P. and Lopez-Ribot, J.L. (2006) Proteomics for the analysis of the Candida albicans biofilm lifestyle. Proteomics 6, 5795- 5804.

Tillmans, J. and Philippi, K. (1929) Über den Gehalt der wichtigsten protein des Nahrungsmittel an Kohlehydraten und über ein kolorimetrisches Verfahren zur quantitativen Bestimmung von stickstoffreien Zucker in Eiweiß. Boochem Z 215, 36-60.

Toledo-Arana, A., Valle, J., Solano, C., Arrizubieta, M.J., Cucarella, C., Lamata, M., Amorena, B., Leiva, J., Penades, J.R. and Lasa, I. (2001) The enterococcal surface protein, Esp, is involved in Enterococcus faecalis biofilm formation. Appl Environ Microbiol 67, 4538-4545.

Tomarelli, R., Charney, J. and Harding, M.L. (1949) The use of azoalbumin as a substrate in the colorimetric determination of peptic and tryptic activity. J Lab Clin Med 34, 428-433.

van der Aa, B.C. and Dufrene, Y.F. (2002) In situ characterization of bacterial extracellular polymeric substances by AFM. Colloids Surf B Biointerfaces 23, 173-182.

Wahl, M. (1989) Marine epibiosis. I. Fouling and antifouling: some basic aspects. Mar Ecol Prog Ser 58, 175-189.

Welin, J., Wilkins, J.C., Beighton, D. and Svensäter, G. (2004) Protein expression by Streptococcus mutans during initial stage of biofilm formation. Appl Environ Microbiol 70, 3736-3741.

Wingender, J., Neu, T.R. and Flemming, H.C. (1999) What are bacterial extracellular polymeric substances? In Microbial extracellular polymeric substances ed. Wingender, J., Neu, T.R. and Flemming, H.C. pp. 1-19. Berlin: Springer. 


\section{Tables}

Table 1 Subtilisin IC50 values calculated from a three-parameter logistic equation fitted to experimental values $(p<0.05)$. Data are shown \pm SD (standard deviation).

\begin{tabular}{lll}
\hline $3 \mathrm{~h}$ adhesion prevention & $24 \mathrm{~h}$ adhesion prevention & $3 \mathrm{~h}$ adhered bacteria detachment \\
\hline $0.0092 \pm 0.0015 \mathrm{UP} \mathrm{ml}^{-1}$ & $0.0007 \pm 0.0001 \mathrm{UP} \mathrm{ml}^{-1}$ & $0.0269 \pm 0.0063 \times 10^{-3} \mathrm{UP} \mathrm{ml}^{-1}$ \\
$0.333 \pm 0.054 \mathrm{mg} \mathrm{ml}^{-1}$ & $0.0252 \pm 0.0049 \mathrm{mg} \mathrm{ml}^{-1}$ & $0.970 \pm 0.227 \mathrm{mg} \mathrm{ml}^{-1}$ \\
\hline
\end{tabular}




\section{Figures}

Figure 1

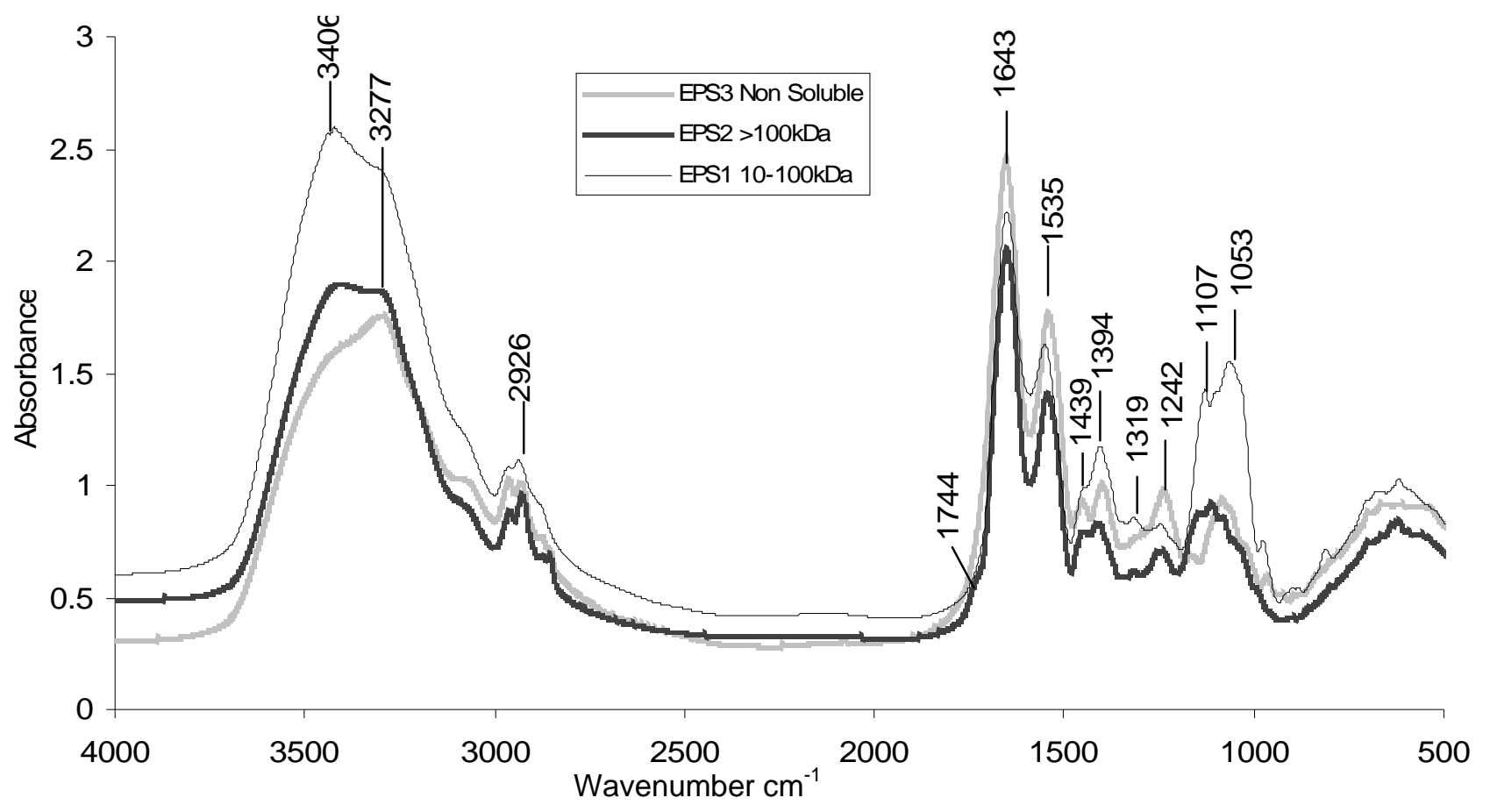

Figure 1 FTIR spectrum of three EPS fractions from Pseudoalteromonas sp. D41 
Figure 2

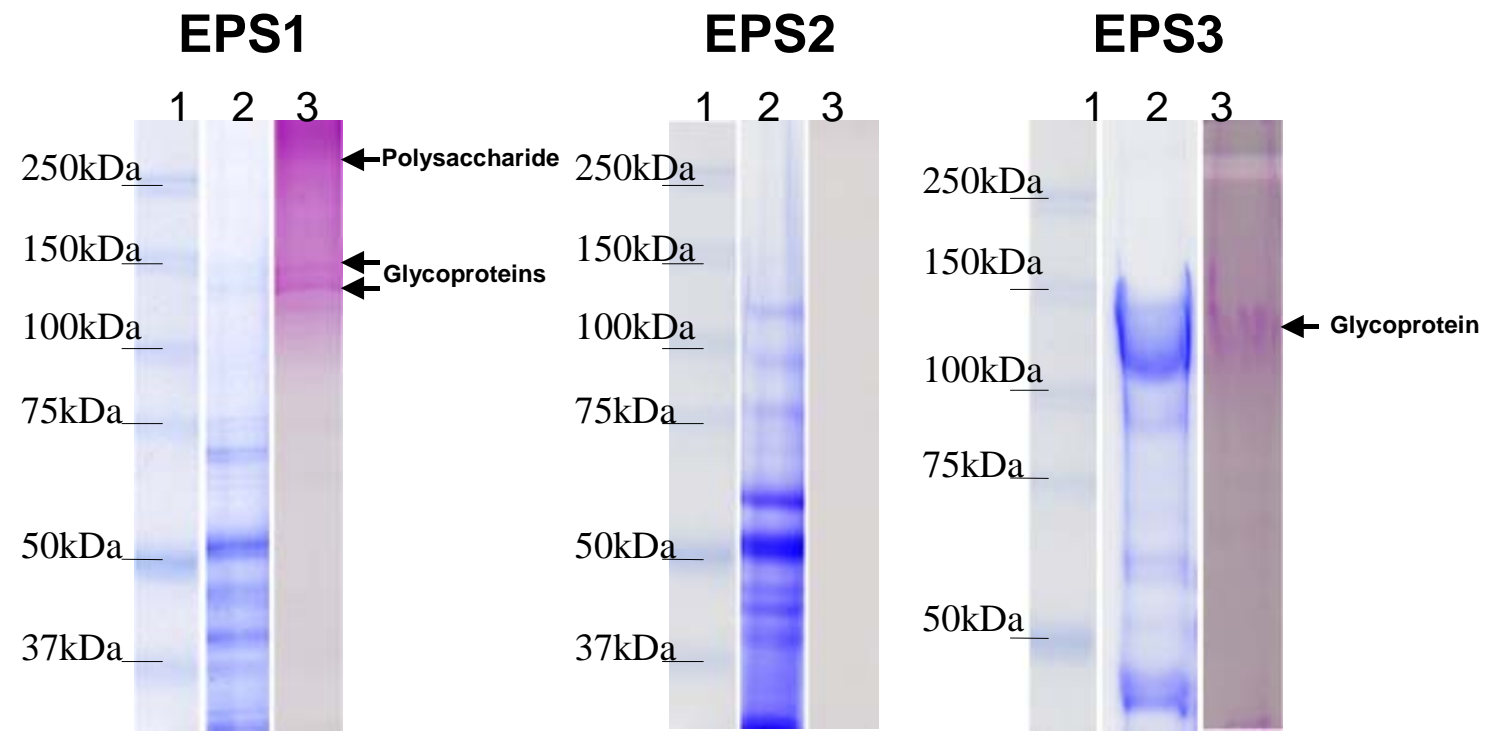

Figure 2 SDS gel (8\%) electrophoresis of three EPS fractions from Pseudoalteromonas sp. D41 stained with Coomassie (lane 2) and Shiff's reagent (lane 3) to detect proteins and carbohydrates respectively. Molecular weight markers are in lane 1.

\section{Figure 3}

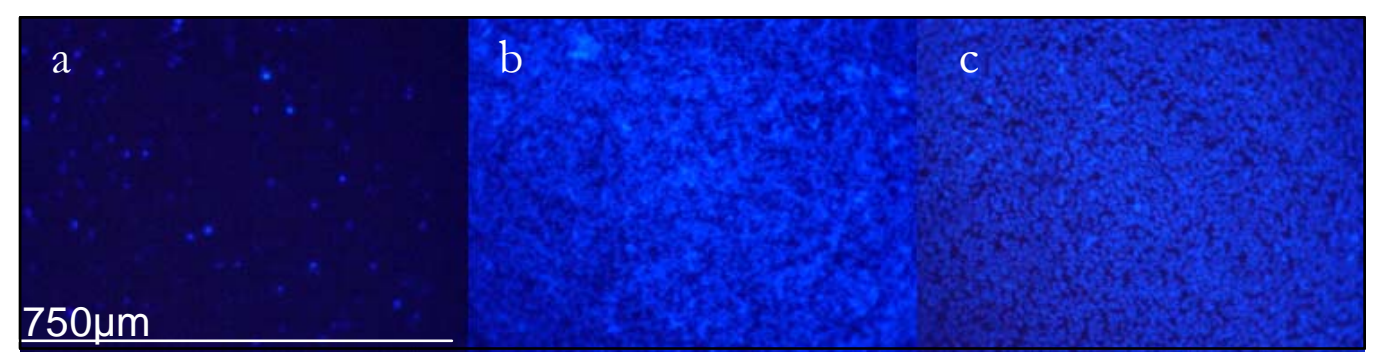

Figure 3 Epifluorescence images of Pseudoalteromonas sp. D41 on glass slide after $24 \mathrm{~h}$ adhesion and stained with calcofluor (a), DAPI (b) and fluorescamine (c). 


\section{Figure 4}

A

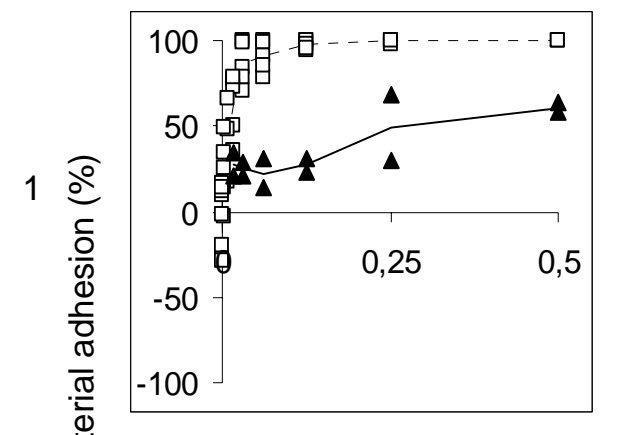

2

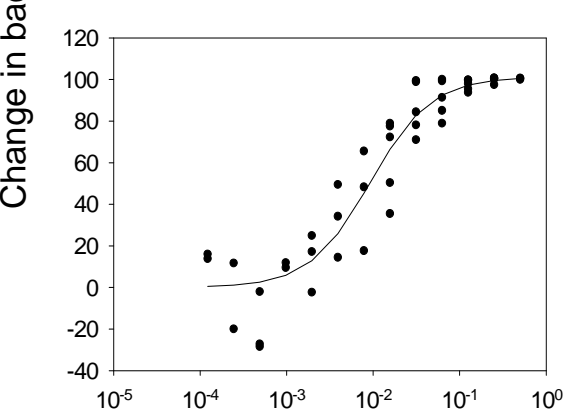

B
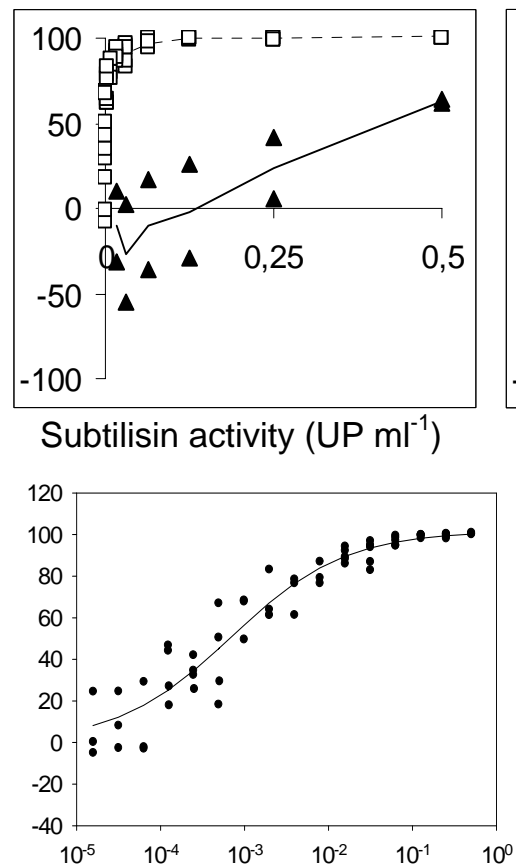

C
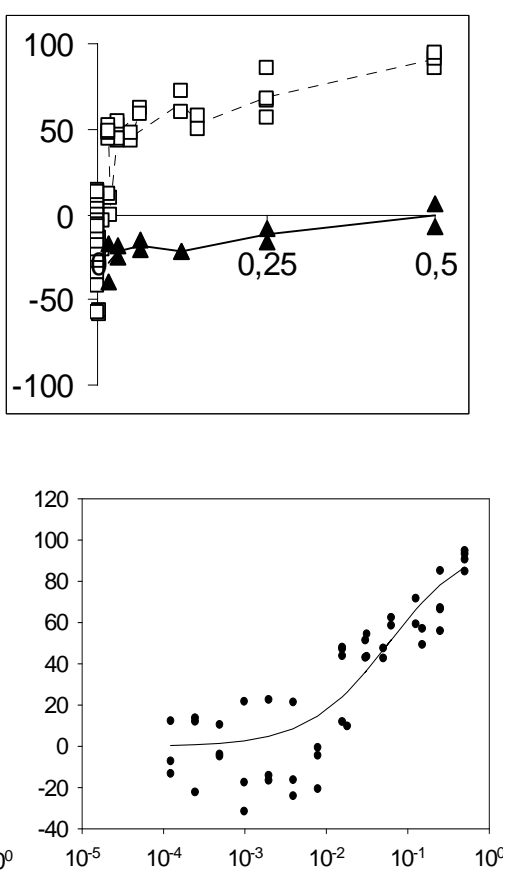

Subtilisin activity (UP ${ }^{-1}$, logarithmic scale)

Figure 4 Percentage reduction of bacterial adhesion in microtiter plates against subtilisin concentrations in the well (UP ml-1) with the three protocols tested: prevention of bacterial adhesion measured after $3 \mathrm{~h}(\mathrm{~A})$, prevention of an adhesion after $24 \mathrm{~h}(\mathrm{~B})$ and detachment of adhered bacteria after $3 \mathrm{~h}(\mathrm{C})$. Row 1, both subtilisin ( $\square$ ) and heat denatured subtilisin ( $\mathbf{\Lambda})$ were represented according to subtilisin concentrations in the well (UP ml-1), curves represent average data. Row 2, same data are represented according to logarithmic scale of subtilisin concentrations in the well (UP I-1), curves represent data fitted to a three-parameter logistic equation. All experimental values are shown; four experiments were tested each enzyme concentration and two each heat denatured enzyme. UP is used for the protease activity unit. 